\title{
Impact of Wheat Cultivation on Microbial Communities from Replant Soils and Apple Growth in Greenhouse Trials
}

\author{
Mark Mazzola and Yu-Huan Gu
}

USDA Agricultural Research Service, Tree Fruit Research Laboratory, 1104 N. Western Avenue, Wenatchee, WA 98801. Accepted for publication 1 November 1999.

\begin{abstract}
Mazzola, M., and Gu, Y.-H. 2000. Impact of wheat cultivation on microbial communities from replant soils and apple growth in greenhouse trials. Phytopathology 90:114-119.

Studies were conducted to assess the impact of short-term rotations of wheat on microbial community composition and growth of apple in soils from replant orchard sites. Soils from two orchards were cultivated with three successive 28-day growth cycles of 'Eltan', 'Penewawa', or 'Rely' wheat in the greenhouse and subsequently planted to 'Gala' apple seedlings. Cultivation of orchard replant soils with any of the three wheat cultivars enhanced growth of apple relative to that achieved in untreated soils. Improved growth was associated with a marked reduction in apple root infection by species of Rhizoctonia and Pythium. Populations of plant-parasitic nematodes were below damage threshold levels in these

had significantly lower root populations of Pratylenchus spp. than did seedlings grown in untreated soils. Growth of apple in 'Penewawa'-cultivated soils often was superior to that observed in soils planted with 'Eltan' or 'Rely'. In untreated orchard soils, fluorescent pseudomonad populations isolated from soil and the apple rhizosphere were dominated by Pseudomonas fluorescens biotype $\mathrm{C}$ and Pseudomonas syringae. Cultivation of replant soils with wheat induced a characteristic transformation of the fluorescent pseudomonad population, and Pseudomonas putida dominated the population of this bacterial group recovered from wheat-cultivated replant orchard soils. Results from this study suggest that use of short-term wheat cropping sequences during orchard renovation could be useful in management of replant disease and that this disease-control option may operate, in part, through modification of the fluorescent pseudomonad community.
\end{abstract} orchard soils; however, apple seedlings grown in wheat-cultivated soils
The poor growth of newly established apple orchards on sites formerly cropped with the same species has been termed apple replant disease. Replant disease is the primary impediment to the establishment of an economically viable orchard on sites previously cropped with apple. In the absence of preplant soil fumigation, trees established on replant sites are often stunted, and the fine root system of symptomatic trees typically exhibits extensive decay $(2,10,25)$. Although abiotic factors may contribute to disease severity, the causal elements of apple replant disease are primarily biotic. This is evidenced by the fact that soil fumigation results in dramatic improvement in tree growth on replant sites $(16,28)$ and that the growth of unrelated tree species on these sites is typically normal (26). In Washington, a complex composed of fungi belonging to the genera Cylindrocarpon, Phytophthora, Pythium, and Rhizoctonia is the primary cause of apple replant disease (18). Historically, replant disease has been considered of primary significance on sites from which old trees were removed. However, recent studies have demonstrated that a microbial complex capable of inciting replant disease symptoms can develop within a few years of orchard establishment (20).

Due to the complex and often uncertain etiology of apple replant disease, its control has relied heavily on the use of preplant soil fumigants that possess a broad spectrum of biological activity $(5,33)$. Although this practice has typically provided adequate disease control, there are numerous disadvantages to the use of these materials, including high costs and potential hazards to human health. The long-term availability of most soil fumigants is in question because a worldwide stepped-phaseout in use of methyl

Corresponding author: M. Mazzola; E-mail address: mazzola@tfrl.ars.usda.gov

Publication no. P-1999-1216-01R

This article is in the public domain and not copyrightable. It may be freely reprinted with customary crediting of the source. The American Phytopathological Society, 2000. bromide has been initiated, and other broad-spectrum biocides face possible regulatory action at both regional and national levels. In addition, the expanding organic tree-fruit industry has few, if any, alternatives to preplant fumigation prior to orchard renovation (8). Thus, alternative approaches to the use of preplant soil fumigants for control of replant disease are highly desired by the tree-fruit industry.

Crop rotation can effectively control soilborne diseases in most agricultural ecosystems. The absence of a susceptible plant host in successive growing seasons can deny soilborne pathogens a substrate suitable for prolonged survival at population densities required to cause significant damage when the host plant is ultimately reestablished on that site. Crop rotation per se is not feasible for control of soilborne diseases in orchard systems due to the perennial nature of the crop. However, cultivation of cover crops during orchard renovation has been suggested as an alternative system for establishment of apple on replant sites. Such studies have targeted the use of cropping systems that promote plant growth through either enhanced nutrient availability (1) or suppression of the lesion nematode, Pratylenchus penetrans $(15,22)$, which has been implicated as a causal agent of replant disease in some regions $(7,12,16,30)$.

Recently, studies were conducted to determine the impact of the apple root system on the composition of the resident soil microflora and the ability of the soil microbial community to suppress Rhizoctonia solani AG 5 (20). Prior to orchard establishment, the site used in the study had been in continuous wheat production. The microbial community that was resident prior to planting the site to apple suppressed an introduced isolate of $R$. solani AG 5 . In contrast, the microbial community recovered from orchard soil that had been in production for 3 years or longer was incapable of suppressing this pathogen. The relative ability of these orchard soils to suppress $R$. solani was associated with specific differences in population size of Burkholderia cepacia and composition of the fluorescent pseudomonad population. The cropping history of this 
site suggested that wheat cultivation may support a microbial community that is suppressive to one or more components of the fungal complex that has a dominant role in apple replant disease in Washington (18). Therefore, the objectives of the current study were to assess the impact of wheat cultivation on microbial community composition and growth of apple in replant orchard soils.

\section{MATERIALS AND METHODS}

Study site and soil collection. These studies were conducted in soil obtained from the Wenatchee Valley College Auvil Research and Demonstration (WVC) and the Columbia View Experimental (CV) orchards, located $6.4 \mathrm{~km}$ east and $19.2 \mathrm{~km}$ north of East Wenatchee, WA, respectively. The WVC orchard is uniform with respect to soil type (Cowiche silt loam) and was cropped continuously with wheat monoculture prior to orchard establishment in 1992. Burch sandy loam is the dominant soil type at the CV orchard. Soils were collected during June and August 1998 from a 17-year-old block of 'Red Delicious' on seedling rootstock at the CV orchard and a 6-year-old block of 'Fuji' on M.26 rootstock at the WVC orchard. For each orchard block, a composite sample was obtained by collecting soil within the root zone of 30 randomly selected trees. Samples were obtained at a depth of 10 to $30 \mathrm{~cm} 1$ to $2 \mathrm{~m}$ from the tree base.

Wheat cultivation. Orchard soils were placed in individual plastic trays $(50 \mathrm{~cm}$ long, $40 \mathrm{~cm}$ wide, $15 \mathrm{~cm}$ deep). Soils were planted with one of the following wheat cultivars: 'Eltan' soft white winter wheat, 'Penewawa' soft white spring wheat, and 'Rely' club wheat. Each tray was planted with $70 \mathrm{~g}$ of seed, with a total of four rows of wheat and $8 \mathrm{~cm}$ between rows. Wheat was grown on a greenhouse bench at $24^{\circ} \mathrm{C}$ without supplemental lighting. Plants were watered twice each week with tap water. Fertilization of plants was not conducted in the course of the experiment. After 28 days, wheat shoots were excised at the soil surface and discarded. Soil was cultivated by hand to disrupt the wheat root system, and soil was replanted to the same wheat cultivar. This process of wheat cultivation was conducted for a total of three cycles. Soils not cultivated with wheat (control) were incubated for the same duration under the same conditions.

Effect of wheat cultivation on growth of apple in replant soils. Apple ('Gala') seed was surface-sterilized in a $10 \%$ solution of commercial bleach (5.25\% sodium hypochlorite) and rinsed for $30 \mathrm{~min}$ under running tap water. Seed was dusted with captan 50WP and stratified for germination by placing seed in a plastic bag with moistened paper towels at $4^{\circ} \mathrm{C}$ for 8 weeks. Seed was sown in plastic flats containing sterile peat moss-perlite growth medium and incubated at $24^{\circ} \mathrm{C}$ with a 12 -h photoperiod until seedling emergence. Seedlings were transferred to environmental chambers and grown at $18^{\circ} \mathrm{C}$ with a 12 -h photoperiod until 8 weeks of age.

Wheat-cultivated and control orchard soils were placed in pots (16 cm diameter) and planted with 8-week-old 'Gala' apple seedlings, with five seedlings per pot and six pots per soil. Plants were grown in the greenhouse at $18^{\circ} \mathrm{C}$ for 14 weeks. At harvest, one plant with associated soil from each pot was set aside for microbial analysis. For the remaining plants, root systems were washed under a stream of tap water, and plant height, shoot weight, and root weight were determined.

Analysis of microorganisms. At the completion of the wheat growth-cycle sequence, but prior to planting apple, the population and composition of fluorescent pseudomonads in each soil were assessed. One soil sample was collected from each pot for each soil treatment and individual suspensions were prepared by placing $0.1 \mathrm{~g}$ of soil in $10 \mathrm{ml}$ of sterile water. Serial dilutions of the suspension were plated on King's medium B agar supplemented with ampicillin $\left(40 \mu \mathrm{g} \mathrm{ml}^{-1}\right)$, chloramphenicol $\left(13 \mu \mathrm{g} \mathrm{ml}^{-1}\right)$, and cycloheximide $\left(100 \mu \mathrm{g} \mathrm{ml}^{-1}\right)\left(\mathrm{KMB}^{+}\right)(27)$. After $72 \mathrm{~h}$ at $28^{\circ} \mathrm{C}$, fluorescing colonies were counted, and for each suspension, 10 randomly selected colonies were transferred to tryptic soy agar (Difco Laboratories, Detroit). Samples were processed and identified by gas chromatography-fatty acid methyl ester analysis as described previously (18).

Six apple seedlings (one per pot) were collected at harvest from each soil treatment and used to assess populations of fluorescent pseudomonads, fungi, and plant-parasitic nematodes colonizing the rhizosphere of apple. For seedlings grown in WVC orchard soil, a composite root sample, totaling $4 \mathrm{~cm}$ long, and associated rhizosphere soil was obtained from each seedling. Root tissue was placed in a test tube with $10 \mathrm{ml}$ of sterile water and vortexed for $60 \mathrm{~s}$. Serial dilutions of the root wash were plated onto $\mathrm{KMB}^{+}$for isolation of fluorescent pseudomonads. Colonies were counted after $72 \mathrm{~h}$ of incubation at $28^{\circ} \mathrm{C}$, and 10 isolates were selected and identified for each sample, as described above.

Prior to further processing, plant roots were washed under a stream of tap water to remove adhering soil. Composition of fungal populations colonizing the roots of apple seedlings grown in each soil was determined. From each of these same six seedlings, 30 root segments ( 0.5 to $1.0 \mathrm{~cm}$ long) were excised and plated on $1.5 \%$ water agar amended with ampicillin $\left(100 \mu \mathrm{g} \mathrm{ml}^{-1}\right)$. After incubation at room temperature $\left(20\right.$ to $\left.23^{\circ} \mathrm{C}\right)$ for $96 \mathrm{~h}$, growth of actinomycetes and fungi emanating from root segments was examined with a light microscope $(100 \times)$. Sporulating fungi and Rhizoctonia spp. were identified to the genus.

Populations of Pratylenchus spp. were determined by placing $1 \mathrm{~g}$ of root tissue from each seedling into individual 125-ml flasks containing $80 \mathrm{ml}$ of sterile water and incubating on a gyrotory shaker (model G2; New Brunswick Scientific Co., Edison, NJ) at $200 \mathrm{rpm}$ for $72 \mathrm{~h}$. For seedlings possessing $<1 \mathrm{~g}$ of root tissue, root biomass was recorded, and all remaining root tissue was used for nematode extraction. Nematodes were collected by filtering soil extract twice through a 350-mesh sieve and backwashing into a counting dish. Pratylenchus spp. were counted with a dissecting microscope.

Data analysis. Studies of the impact of wheat cultivation on growth of apple, composition of fungal communities recovered from apple roots, and nematode populations were conducted twice in each soil (trial 1 and 2). However, composition of bacterial communities as impacted by wheat cultivation was assessed only in the first trial. Similar changes in plant growth, composition of fungal community, and populations of Pratylenchus spp. were obtained in response to wheat cultivation of replant soils in the two inde-

TABLE 1. Impact of short-term wheat cultivation in Columbia View Experimental (CV) and Wenatchee Valley College Auvil Research and Demonstration (WVC), WA, orchard soils on subsequent growth of 'Gala' apple seedlings ${ }^{\mathrm{y}}$

\begin{tabular}{|c|c|c|c|c|c|c|}
\hline \multirow[b]{2}{*}{ Wheat cultivar } & \multicolumn{3}{|c|}{$\mathrm{CV}$} & \multicolumn{3}{|c|}{ WVC } \\
\hline & Height $(\mathrm{cm})$ & Shoot weight (g) & Root weight (g) & Height $(\mathrm{cm})$ & Shoot weight (g) & Root weight (g) \\
\hline Control $^{z}$ & $9.2 \mathrm{a}$ & $1.04 \mathrm{a}$ & $0.91 \mathrm{a}$ & $5.6 \mathrm{a}$ & $0.48 \mathrm{a}$ & $0.39 \mathrm{a}$ \\
\hline Eltan & $17.4 \mathrm{~b}$ & $2.89 \mathrm{~b}$ & $2.05 \mathrm{~b}$ & $11.1 \mathrm{~b}$ & $1.67 \mathrm{~b}$ & $0.99 \mathrm{~b}$ \\
\hline Penewawa & $18.2 \mathrm{~b}$ & $3.54 \mathrm{~b}$ & $2.90 \mathrm{c}$ & $14.6 \mathrm{c}$ & $2.66 \mathrm{c}$ & $1.45 \mathrm{c}$ \\
\hline Rely & $17.3 \mathrm{~b}$ & $3.25 \mathrm{~b}$ & $1.96 \mathrm{~b}$ & $14.0 \mathrm{c}$ & $2.46 \mathrm{c}$ & $1.06 \mathrm{~b}$ \\
\hline
\end{tabular}

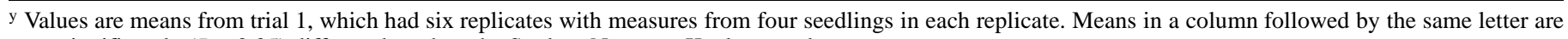
not significantly $(P=0.05)$ different based on the Student-Newman-Keuls procedure.

${ }^{\mathrm{z}}$ Replant soils from the orchards not cultivated to wheat. 
pendent experiments. Data presented are from the initial experiment. Data were subjected to analysis of variance and means separation using the Student-Newman-Keuls method. Percent data were transformed to arcsine-square root values prior to analysis.

\section{RESULTS}

Impact of wheat cultivation on growth of apple. Prior cultivation with wheat significantly improved growth of 'Gala' apple seedlings in $\mathrm{CV}$ and WVC orchard replant soils (Table 1). In certain instances, differential growth responses were observed among apple seedlings grown in orchard soils cultivated with the different wheat cultivars. Seedling root weights were significantly greater in orchard replant soils cultivated with 'Penewawa' than in the corresponding orchard soils cultivated with 'Eltan' or 'Rely'. Likewise, plant height and shoot weight of seedlings grown in WVC orchard replant soil cultivated to either 'Penewawa' or 'Rely' were significantly greater than that of apple grown in soil planted with 'Eltan'.

Fungi recovered from apple seedling roots. Species of Cylindrocarpon, Fusarium, Pythium, and Rhizoctonia comprised $>80 \%$ of the fungal community recovered from apple seedlings grown in $\mathrm{CV}$ and WVC orchard soils previously cropped to apple. Cylindrocarpon and Rhizoctonia were the most prominent genera among the fungal populations recovered from roots of apple seedlings grown in CV (Table 2) and WVC (Table 3) orchard soils, respectively. Cultivating orchard soils with wheat prior to planting apple in either soil resulted in dramatic and consistent changes in the fungal community recovered from the roots of seedlings grown in these soils. Without exception, apple root infection by species of Rhizoctonia and Pythium was significantly reduced or entirely eliminated in response to prior wheat cultivation. Suppression of apple root infection by Pythium spp. was similar regardless of wheat cultivar, but prior cultivation of replant soils with 'Penewawa' or 'Eltan' provided superior results compared with 'Rely' for suppression of Rhizoctonia spp. in CV orchard soil. Prior cultivation

TABLE 2. Effect of short-term wheat cultivation on frequency of recovery of dominant fungal genera from roots of 'Gala' apple seedlings grown in Columbia View Experimental (CV), WA, orchard replant soily

\begin{tabular}{lcccc}
\hline & \multicolumn{4}{c}{ Genus } \\
\cline { 2 - 5 } Wheat cultivar & Cylindrocarpon & Fusarium & Pythium & Rhizoctonia \\
\hline Control $^{\mathrm{z}}$ & $28.5 \mathrm{ab}$ & $2.2 \mathrm{a}$ & $6.9 \mathrm{~b}$ & $26.1 \mathrm{c}$ \\
Eltan & $47.1 \mathrm{c}$ & $16.0 \mathrm{bc}$ & $2.2 \mathrm{a}$ & $8.1 \mathrm{a}$ \\
Penewawa & $36.2 \mathrm{~b}$ & $23.8 \mathrm{c}$ & $1.4 \mathrm{a}$ & $1.9 \mathrm{a}$ \\
Rely & $20.0 \mathrm{a}$ & $8.9 \mathrm{ab}$ & $1.9 \mathrm{a}$ & $16.7 \mathrm{~b}$ \\
\hline
\end{tabular}

$\mathrm{y}$ Values are from trial 1 and indicate the percentage of the total number of root segments from which fungi of a given genus were isolated. Fungi were isolated from 30 root segments for one seedling in each of six replicates. Values in a column followed by the same letter are not significantly $(P=$ 0.05 ) different based on the Student-Newman-Keuls procedure.

${ }^{\mathrm{z}}$ Replant soils from the CV orchard not cultivated to wheat.

TABLE 3. Effect of short-term wheat cultivation on frequency of recovery of dominant fungal genera from roots of 'Gala' apple seedlings grown in Wenatchee Valley College Auvil Research and Demonstration (WVC), WA, orchard replant soily

\begin{tabular}{lcccc}
\hline & \multicolumn{4}{c}{ Genus } \\
\cline { 2 - 5 } Wheat cultivar & Cylindrocarpon & Fusarium & Pythium & Rhizoctonia \\
\hline Control $^{\mathrm{z}}$ & $9.4 \mathrm{a}$ & $9.4 \mathrm{a}$ & $6.5 \mathrm{~b}$ & $24.4 \mathrm{~b}$ \\
Eltan & $2.2 \mathrm{a}$ & $29.3 \mathrm{~b}$ & $0 \mathrm{a}$ & $4.0 \mathrm{a}$ \\
Penewawa & $9.4 \mathrm{a}$ & $47.3 \mathrm{c}$ & $0 \mathrm{a}$ & $0.6 \mathrm{a}$ \\
Rely & $5.0 \mathrm{a}$ & $30.0 \mathrm{~b}$ & $1.7 \mathrm{a}$ & $2.5 \mathrm{a}$ \\
\hline
\end{tabular}

${ }^{y}$ Values are from trial 1 and indicate the percentage of the total number of root segments from which fungi of a given genus were isolated. Fungi were isolated from 30 root segments for one seedling in each of six replicates. Values in a column followed by the same letter are not significantly $(P=$ 0.05 ) different based on the Student-Newman-Keuls procedure.

${ }^{\mathrm{z}}$ Replant soils from the WVC orchard not cultivated to wheat. of replant soils with wheat did not reduce subsequent colonization of apple roots by Cylindrocarpon spp., and in CV soil, recovery of Cylindrocarpon spp. was greater from seedlings grown in soil cultivated to 'Eltan' relative to the control. Recovery of Fusarium spp. from apple roots was consistently higher in soils cultivated to wheat prior to planting.

Effect of wheat cultivation on populations of Pratylenchus spp. Prior cultivation of replant soils from this site had a significant impact on populations of Pratylenchus spp. recovered from the roots of apple seedlings grown in these soils (Table 4). Lesion nematode populations ranged from $10.8 \mathrm{~g}$ per root for seedlings grown in CV orchard soil to $30.5 \mathrm{~g}$ per root in WVC replant soil. Regardless of the orchard or prior cropping history, seedlings grown in wheat-cultivated soils possessed significantly lower populations of Pratylenchus spp., and there were no significant differences among soils cultivated with different wheat cultivars.

Fluorescent pseudomonads isolated from soil and apple rhizosphere. Fluorescent pseudomonad populations in CV and WVC orchard replant soils averaged 7.9 and $1.3 \times 10^{5} \mathrm{CFU} / \mathrm{g}$ of soil, respectively. Wheat cultivation resulted in a significant $(P=0.05)$ increase in soil populations of fluorescent pseudomonads to at least $1.2 \times 10^{6} \mathrm{CFU} / \mathrm{g}$ of $\mathrm{CV}$ soil and $9.4 \times 10^{5} \mathrm{CFU} / \mathrm{g}$ of $\mathrm{WVC}$ soil. The fluorescent pseudomonad population from both replant soils was dominated by Pseudomonas fluorescens biotype C (Tables 5 and 6). Cultivation of either replant soil with wheat resulted in a reduction in the relative population of Pseudomonas fluorescens biotype $\mathrm{C}$ and a concomitant increase in Pseudomonas putida. Replant orchard soils cultivated with 'Eltan' and 'Rely' possessed the highest relative populations of Pseudomonas putida and Pseudomonas syringae, respectively.

TABLE 4. Impact of short-term wheat cultivation of orchard soils on apple seedling root populations of Pratylenchus spp.

\begin{tabular}{lrr}
\hline & \multicolumn{2}{c}{ Orchard soil $^{\mathrm{y}}$} \\
\cline { 2 - 3 } Wheat cultivar & $\mathrm{CV}$ & WVC \\
\hline Control $^{\mathrm{z}}$ & $10.8 \mathrm{a}$ & $30.5 \mathrm{a}$ \\
Eltan & $2.6 \mathrm{~b}$ & $1.7 \mathrm{~b}$ \\
Penewawa & $0.8 \mathrm{~b}$ & $3.0 \mathrm{~b}$ \\
Rely & $2.0 \mathrm{~b}$ & $2.3 \mathrm{~b}$
\end{tabular}

${ }^{y}$ Numbers of Pratylenchus spp. per g of root. CV = Columbia View Experimental orchard, WA, and WVC $=$ Wenatchee Valley College Auvil Research and Demonstration orchard, WA. Values are means from trial 1 and are based on populations determined from one seedling in each of six replicates. Means in a column followed by the same letter are not significantly $(P=$ $0.05)$ different based on the Student-Newman-Keuls procedure.

${ }^{\mathrm{z}}$ Replant soils from the orchards not cultivated to wheat.

TABLE 5. Impact of wheat cultivation on composition of soil populations of fluorescent pseudomonads in Columbia View Experimental orchard, WA, soil ${ }^{\mathrm{y}}$

\begin{tabular}{lcccc}
\hline & \multicolumn{4}{c}{ Wheat cultivar } \\
\cline { 2 - 5 } Pseudomonas species & Control $^{\mathrm{z}}$ & Eltan & Penewawa & Rely \\
\hline P. aureofaciens & $5.8 \mathrm{a}$ & $0 \mathrm{a}$ & $5.0 \mathrm{a}$ & $0 \mathrm{a}$ \\
P. fluorescens biotype A & $0 \mathrm{a}$ & $3.3 \mathrm{a}$ & $1.7 \mathrm{a}$ & $3.3 \mathrm{a}$ \\
P. fluorescens biotype B & $0 \mathrm{a}$ & $0 \mathrm{a}$ & $0 \mathrm{a}$ & $1.7 \mathrm{a}$ \\
P. fluorescens biotype C & $55.0 \mathrm{~b}$ & $11.7 \mathrm{a}$ & $18.3 \mathrm{a}$ & $25.0 \mathrm{a}$ \\
P. fluorescens biotype F & $11.7 \mathrm{a}$ & $3.3 \mathrm{a}$ & $4.2 \mathrm{a}$ & $0 \mathrm{a}$ \\
P. fluorescens biotype G & $0 \mathrm{a}$ & $1.7 \mathrm{a}$ & $0 \mathrm{a}$ & $1.7 \mathrm{a}$ \\
P. marginalis & $0.8 \mathrm{a}$ & $0 \mathrm{a}$ & $4.2 \mathrm{a}$ & $0 \mathrm{a}$ \\
P. putida & $3.3 \mathrm{a}$ & $56.7 \mathrm{c}$ & $43.3 \mathrm{bc}$ & $22.5 \mathrm{~b}$ \\
P. syringae & $17.5 \mathrm{a}$ & $16.7 \mathrm{a}$ & $17.5 \mathrm{a}$ & $38.3 \mathrm{~b}$ \\
Unknown & 5.8 & 8.3 & 5.8 & 7.5 \\
\hline
\end{tabular}

y Values are based on data from trial 1 and represent the percentage of the total number of fluorescent pseudomonads examined for a given soil treatment. A total of 10 randomly selected isolates from each of six soil samples was identified. Values in a row followed by the same letter are not significantly $(P=0.05)$ different based on the Student-Newman-Keuls procedure.

${ }^{\mathrm{z}}$ Replant soils from the orchards not cultivated to wheat. 
As was observed in soil, cultivation of WVC orchard soil with wheat prior to planting had a significant impact on the composition of the fluorescent pseudomonad population recovered from the rhizosphere of 'Gala' apple seedlings. The relative rhizosphere population of Pseudomonas fluorescens biotype C, in general, was reduced by prior cultivation of WVC orchard replant soil with wheat, whereas the population of Pseudomonas putida was enhanced (Table 7). The fluorescent pseudomonad population from the rhizosphere of apple seedlings grown in 'Penewawa'-cultivated soil possessed a higher relative population of Pseudomonas putida than did seedlings grown in soils planted to 'Eltan' or 'Rely'.

Recovery of actinomycetes from apple seedling roots. Root segments used to survey the fungal community colonizing apple seedlings grown in replant soils also were examined for the presence of actinomycetes. In general, fewer actinomycetes were recovered from seedlings grown in $\mathrm{CV}$ or WVC orchard replant soils than the corresponding soils cultivated with wheat (Table 8). Frequency of actinomycete isolation was significantly higher from apple seedlings grown in replant soils cultivated with 'Rely' than from soils cultivated with 'Eltan' or 'Penewawa'.

\section{DISCUSSION}

Preplant soil fumigation is the conventional practice employed to eliminate biotic causal agents of apple replant disease during orchard renovation. However, the impending loss of specific fumigants due to regulatory actions, an increased interest in the use of sustainable pest control methods in orchard management, and an expanding and profitable organic tree-fruit industry necessitate the development of economically viable alternatives to soil fumigants for controlling this disease.

Control of diseases caused by species of Pythium and Rhizoctonia has been achieved through crop rotation in some agricultural systems, but due to the broad host range of many of these fungi, there are instances where this practice will not provide disease control $(4,6,11)$. Nevertheless, results from our study indicate that wheat cover cropping during orchard renovation may reduce incidence of root infection by both Pythium spp. and Rhizoctonia spp. and thereby improve growth of apple in replant soils. Increased recovery of Cylindrocarpon spp. from apple roots in response to wheat cultivation points to a recurring difficulty in managing replant diseases in the absence of broad-spectrum soil fumigants and demonstrates the need to develop a control system that targets all components of this pathogen complex.

The ability of wheat cultivation to enhance growth of apple in replant soils may result from the diminished availability of the substrate necessary for survival of species of Rhizoctonia and Pythium pathogenic to apple. Although these root pathogens pos-

TABLE 6. Impact of wheat cultivation on composition of soil populations of fluorescent pseudomonads in Wenatchee Valley College Auvil Research and Demonstration orchard, WA, replant soil ${ }^{\mathrm{y}}$

\begin{tabular}{lcccc}
\hline & \multicolumn{4}{c}{ Wheat cultivar } \\
\cline { 2 - 5 } Pseudomonas species & Control $^{\mathrm{z}}$ & Eltan & Penewawa & Rely \\
\hline P. aureofaciens & $1.7 \mathrm{a}$ & $4.2 \mathrm{a}$ & $1.7 \mathrm{a}$ & $0 \mathrm{a}$ \\
$P$. fluorescens biotype A & $0 \mathrm{a}$ & $1.7 \mathrm{a}$ & $0 \mathrm{a}$ & $3.3 \mathrm{a}$ \\
$P$. fluorescens biotype C & $51.7 \mathrm{~b}$ & $5.0 \mathrm{a}$ & $13.3 \mathrm{a}$ & $5.8 \mathrm{a}$ \\
$P$. fluorescens biotype $\mathrm{F}$ & $1.7 \mathrm{a}$ & $16.7 \mathrm{~b}$ & $12.5 \mathrm{~b}$ & $15.8 \mathrm{~b}$ \\
$P$. fluorescens biotype G & $0.8 \mathrm{a}$ & $0.8 \mathrm{a}$ & $3.3 \mathrm{a}$ & $1.7 \mathrm{a}$ \\
$P$. marginalis & $0 \mathrm{a}$ & $0 \mathrm{a}$ & $2.5 \mathrm{a}$ & $0 \mathrm{a}$ \\
$P$. putida & $15.0 \mathrm{a}$ & $41.7 \mathrm{~b}$ & $35.0 \mathrm{~b}$ & $29.1 \mathrm{ab}$ \\
$P$. syringae & $20.8 \mathrm{a}$ & $16.7 \mathrm{a}$ & $18.3 \mathrm{a}$ & $35.0 \mathrm{~b}$ \\
Unknown & 8.3 & 13.3 & 13.3 & 9.2 \\
\hline
\end{tabular}

$\mathrm{y}$ Values are based on data from trial 1 and represent the percentage of the total number of fluorescent pseudomonads examined for a given soil treatment. A total of 10 randomly selected isolates from each of six soil samples was identified. Values in a row followed by the same letter are not significantly $(P=0.05)$ different based on the Student-Newman-Keuls procedure.

${ }^{\mathrm{z}}$ Replant soils from the orchards not cultivated to wheat. sess a wide host range, apparently few species have the ability to infect both apple and wheat. For instance, in the Pacific Northwest, $R$. solani AG 8 is the primary causal agent of Rhizoctonia root rot of wheat $(23,29)$, but $R$. solani AG 5 is the dominant species of Rhizoctonia associated with replant disease of apple $(17,18)$. In eastern Washington, 10 species of Pythium are associated with Pythium root rot of wheat (3), and 14 species of Pythium have been identified from apple (21). Pythium ultimum var. sporangiiferum and Pythium irregulare appear to be the dominant species associated with wheat in this region (9), whereas preliminary evidence suggests that Pythium sylvaticum, Pythium heterothallicum, and Pythium macrosporum are the most virulent on apple (21). Thus, the apparent control of species of Pythium and Rhizoctonia on apple may have resulted from selection of populations of these fungi by wheat, which are not pathogenic to apple.

Alternatively, the beneficial impact of wheat rotation on subsequent growth of apple in replant soil could be due, in part, to the selection of a resident microbial population antagonistic to species of Pythium and Rhizoctonia. It was previously demonstrated that the microbial community in nonreplant soil from the WVC orchard was suppressive to an introduced isolate of $R$. solani AG 5 (20). In contrast, soil from this site that was cultivated to apple for 3 years or longer had lost the ability to suppress this pathogen. The changes in relative disease-suppressive capabilities of WVC orchard soils were associated with characteristic differences in microbial community structure. For instance, the fluorescent pseudomonad population was dominated by Pseudomonas putida in nonreplant soil but by Pseudomonas fluorescens biotype C in replant soil from this site (20).

Similarly, in the current study, reduced incidence of apple root infection by Pythium and Rhizoctonia spp. in response to cultiva-

TABLE 7. Impact of prior wheat cultivation on composition of the fluorescent pseudomonad population recovered from the rhizosphere of 'Gala' apple seedlings grown in Wenatchee Valley College Auvil Research and Demonstration orchard, WA, replant soily

\begin{tabular}{lcccc}
\hline & \multicolumn{4}{c}{ Wheat cultivar } \\
\cline { 2 - 5 } Pseudomonas species & Control $^{\mathrm{z}}$ & Eltan & Penewawa & Rely \\
\hline P. fluorescens biotype A & $0.8 \mathrm{a}$ & $0 \mathrm{a}$ & $0 \mathrm{a}$ & $4.2 \mathrm{a}$ \\
$P$. fluorescens biotype C & $24.2 \mathrm{~b}$ & $2.5 \mathrm{a}$ & $5.8 \mathrm{a}$ & $12.5 \mathrm{ab}$ \\
$P$. fluorescens biotype $\mathrm{F}$ & $22.5 \mathrm{ab}$ & $16.7 \mathrm{a}$ & $11.7 \mathrm{a}$ & $30.0 \mathrm{~b}$ \\
$P$. fluorescens biotype G & $0 \mathrm{a}$ & $3.3 \mathrm{a}$ & $3.3 \mathrm{a}$ & $0.8 \mathrm{a}$ \\
P. putida & $7.5 \mathrm{a}$ & $18.3 \mathrm{ab}$ & $43.3 \mathrm{c}$ & $21.7 \mathrm{~b}$ \\
$P$. syringae & $40.0 \mathrm{~b}$ & $49.2 \mathrm{~b}$ & $23.3 \mathrm{a}$ & $25.0 \mathrm{a}$ \\
Unknown & 5.0 & 10.0 & 2.5 & 5.8
\end{tabular}

y Values are based on data from trial 1 and represent the percentage of the total number of fluorescent pseudomonads examined for a given soil treatment. A total of 10 randomly selected isolates from one seedling in each of six replicates was identified. Values in a row followed by the same letter are not significantly $(P=0.05)$ different based on the Student-Newman-Keuls procedure.

${ }^{\mathrm{z}}$ Replant soils from the orchards not cultivated to wheat.

TABLE 8. Impact of short-term wheat rotation on frequency of actinomycetes in roots of apple seedlings grown in orchard soils

\begin{tabular}{lrc}
\hline & \multicolumn{2}{c}{ Orchard soil $^{\mathrm{y}}$} \\
\cline { 2 - 3 } Wheat cultivar & $\mathrm{CV}$ & WVC \\
\hline Control $^{\mathrm{z}}$ & $1.1 \mathrm{a}$ & $2.8 \mathrm{a}$ \\
Eltan & $5.8 \mathrm{a}$ & $13.3 \mathrm{a}$ \\
Penewawa & $18.0 \mathrm{~b}$ & $17.7 \mathrm{ab}$ \\
Rely & $34.3 \mathrm{c}$ & $32.7 \mathrm{~b}$ \\
\hline
\end{tabular}

${ }^{\text {y }} \mathrm{CV}=$ Columbia View Experimental orchard, WA, and WVC = Wenatchee Valley College Auvil Research and Demonstration orchard, WA. Values are from trial 1 and indicate the percentage of the total number of root segments from which actinomycetes were recovered. Isolations were conducted from 30 root segments for one seedling in each of six replicates. Values in a column followed by the same letter are not significantly $(P=0.05)$ different based on the Student-Newman-Keuls procedure.

${ }^{\mathrm{z}}$ Replant soils from the orchards not cultivated to wheat. 
tion of soils with wheat were associated with characteristic changes in the composition of fluorescent pseudomonad populations in orchard soils. Pseudomonas fluorescens biotype C was the primary fluorescent pseudomonad in both orchard replant soils prior to wheat cultivation, but Pseudomonas putida dominated the population isolated from soils after cultivation with wheat. In addition, Pseudomonas putida was a significant component of the fluorescent pseudomonad population in the rhizosphere of apple seedlings grown in WVC orchard replant soils that were cultivated with wheat. The majority of Pseudomonas putida, but not Pseudomonas fluorescens biotype $\mathrm{C}$, isolates from this site possess the ability to suppress growth of Pythium and Rhizoctonia spp. (20) and provide biocontrol of Rhizoctonia root rot of apple (19). These observations suggest that altering the composition of fluorescent pseudomonad populations may, in part, be a mechanism that contributed to enhanced growth of apple in replant orchard soils cultivated to wheat.

In several instances, growth of apple after cultivation of orchard soils to 'Penewawa' was superior to that obtained in the same soil planted to 'Eltan' or 'Rely'. In at least one case, this may have resulted from differential suppression of Rhizoctonia spp. pathogenic to apple. Fluorescent pseudomonad populations in soils cultivated to different wheat cultivars possessed similar proportions of Pseudomonas putida. However, it is interesting that the relative population of Pseudomonas putida in the rhizosphere of apple was greater in soil cultivated with 'Penewawa' rather than 'Eltan' or 'Rely'. The ability of the plant rhizosphere to select for specific genotypic and phenotypic populations of fluorescent pseudomonads has been documented previously $(13,14)$. Likewise, Weller (31) demonstrated that wheat cultivars exhibit a differential ability to support populations of the biocontrol agent Pseudomonas fluorescens 2-79. It is possible that the 'Penewawa' rhizosphere selected for a Pseudomonas putida population with an enhanced inherent ability to colonize the apple rhizosphere and suppress $R$. solani.

Actinomycetes are one among numerous groups of microorganisms reported to have a causal role in apple replant disease $(24,32)$. Confirmation of the role of these organisms in replant problems awaits the identification of isolates that are directly capable of functioning as pathogens of apple. In this study, actinomycetes were observed in 1 to $3 \%$ of root fragments from apple seedlings grown in replant orchard soils. However, the relative recovery of actinomycetes from apple seedling roots was unaffected or significantly enhanced by prior cultivation of wheat in orchard replant soils. This finding suggests that actinomycetes may not have a direct role in the growth suppression of apple in these orchard soils. Alternatively, these results may indicate that wheat selects for an actinomycete population that is not pathogenic to apple.

Previous studies have demonstrated the utility of orchard groundcover management for control of the root lesion nematode on apple (22). Plant-parasitic nematodes, Pratylenchus spp. in particular, do not appear to have a dominant role in replant disease of apple in Washington and were not present in large numbers at either study site. Regardless, prior cultivation of orchard soils with any of three wheat cultivars examined in this study resulted in significant reductions in apple root populations of Pratylenchus spp. Thus, cropping wheat prior to orchard renovation may be useful in managing lesion nematodes on replant sites where Pratylenchus spp. are abundant or where this nematode interacts with other soilborne pathogens to incite apple replant disease.

Although enhanced growth of apple in soils from sites with replant problems has been achieved through use of certain cover crops (22), the response was not necessarily correlated with diminished populations or activity of putative causal agents. For instance, both marigold and saia oats significantly enhanced growth of apple in orchard replant soils, but only marigold had a significant impact on populations of the target pest, Pratylenchus penetrans (22). In the same study, a weed-free fallow significantly reduced populations of Pratylenchus penetrans but did not enhance growth of apple. As indicated by the authors, this finding suggests that some other unaccounted-for agent was contributing to disease development.

In contrast, the wheat cultivation scheme used in the current study consistently enhanced growth of apple and diminished populations and activity of various pathogenic organisms, including Pythium spp., Rhizoctonia spp., and Pratylenchus penetrans. Reduced disease incidence in wheat-cultivated soils may have resulted from selection of a soil microbial community suppressive to these pathogens. Effective use of this system for control of replant disease will require a more complete understanding of the microbial communities that contribute to disease suppression. Clearly, validation in field trials across orchard replant sites having pathogen complexes that vary in composition will be required prior to adoption and implementation of such a system by producers.

\section{ACKNOWLEDGMENTS}

We thank K. Mullinex and the Wenatchee Valley College Pomology Program for use of the Auvil Research and Demonstration Orchard, E. L. Valdez and S. K. Ivanov for excellent technical assistance, and P. L. Pusey and B. K. Schroeder for critical review of the manuscript.

\section{LITERATURE CITED}

1. Biggs, A. R., Baugher, T. A., Collins, A. R., Hogmire, H. W., Kotcon, J. B., Glenn, M., Sexstone, A. J., and Byers, R. E. 1997. Growth of apple trees, nitrate mobility and pest populations following a corn versus fescue crop rotation. Am. J. Altern. Agric. 12:162-172.

2. Caruso, F. L., Neubauer, B. F., and Begin, M. D. 1989. A histological study of apple roots affected by replant disease. Can. J. Bot. 67:742-749.

3. Chamswarng, C., and Cook, R. J. 1985. Identification and comparative pathogenicity of Pythium species from wheat roots and wheat-field soils in the Pacific Northwest. Phytopathology 75:821-827.

4. Cook, R. J., and Veseth, R. J. 1991. Wheat Health Management. The American Phytopathological Society, St. Paul, MN.

5. Covey, R. P., Jr., Benson, N. R., and Haglund, W. A. 1979. Effect of soil fumigation on the apple replant disease in Washington. Phytopathology 69:684-686.

6. Davis, R. M., and Nunez, J. J. 1999. Influence of crop rotation on the incidence of Pythium- and Rhizoctonia-induced carrot root dieback. Plant Dis. 83:146-148.

7. Dullahide, S. R., Stirling, G. R., Nikulin, A., and Stirling, A. M. 1994. The role of nematodes, fungi, bacteria, and abiotic factors in the etiology of apple replant problems in the Granite Belt of Queensland. Aust. J. Exp. Agric. 34:1177-1182.

8. Granatstein, D. 1997. Soil quality and fruit production, a connection. Good Fruit Grow. 48:14-16.

9. Hering, T. F., Cook, R. J., and Tang, W.-H. 1987. Infection of wheat embryos by Pythium species during seed germination and the influence of seed age and soil matric potential. Phytopathology 77:1104-1108.

10. Hoestra, H. 1968. Replant diseases of apple in the Netherlands. Ph.D. thesis. Mededelingen van de Landbouwhogeschool, Wageningen, the Netherlands.

11. Ingram, D. M., and Cook, R. J. 1990. Pathogenicity of four Pythium species to wheat, barley, peas and lentils. Plant Pathol. 39:110-117.

12. Jaffee, B. A., Abawi, G. S., and Mai, W. F. 1982. Role of soil microflora and Pratylenchus penetrans in apple replant disease. Phytopathology 72 : $247-251$

13. Latour, X., Corberand, T., Laguerre, G., Allard, F., and Lemanceau, P. 1996. The composition of fluorescent pseudomonad populations associated with roots is influenced by plant and soil type. Appl. Environ. Microbiol. 62:2449-2456.

14. Lemanceau, P., Corberand, T., Gardan, L., Latour, X., Laguerre, G., Boeufgras, J.-M., and Alabouvette, C. 1995. Effect of two plant species, flax (Linum usitatissinum L.) and tomato (Lycopersicon esculentum Mill.) on the diversity of soilborne populations of fluorescent pseudomonads. Appl. Environ. Microbiol. 61:1004-1012.

15. MacDonald, D. H., and Mai, W. F. 1963. Suitability of various cover crops as hosts for the lesion nematode (Pratylenchus penetrans). Phytopathology 53:730-731.

16. Mai, W. F., and Abawi, G. S. 1981. Controlling replant disease of pome and stone fruits in northeastern United States by preplant fumigation. Plant Dis. 65:859-864.

17. Mazzola, M. 1997. Identification and pathogenicity of Rhizoctonia spp. 
isolated from apple roots and orchard soils. Phytopathology 87:582-587.

18. Mazzola, M. 1998. Elucidation of the microbial complex having a causal role in the development of apple replant disease in Washington. Phytopathology 88:930-938.

19. Mazzola, M. 1998. Towards the development of sustainable alternatives for the control of apple replant disease in Washington. Pages 8.1-8.3 in: Proc. Annu. Int. Res. Conf. Methyl Bromide Altern. Emiss. Reductions. U. S. Environmental Protection Agency and U. S. Department of Agriculture, Washington, DC.

20. Mazzola, M. 1999. Transformation of soil microbial community structure and Rhizoctonia-suppressive potential in response to apple roots. Phytopathology 89:920-927.

21. Mazzola, M., and Lévesque, C. A. 1999. Diversity in species composition and sensitivity to metalaxyl among isolates of Pythium from apple replant soils. (Abstr.) Phytopathology 89(suppl.):S50.

22. Merwin, E. A., and Stiles, W. C. 1989. Root-lesion nematodes, potassium deficiency, and prior cover crops as factors in apple replant disease. J. Am. Soc. Hortic. Sci. 114:724-728.

23. Ogoshi, A., Cook, R. J., and Bassett, E. N. 1990. Rhizoctonia species and anastomosis groups causing root rot of wheat and barley in the $\mathrm{Pa}-$ cific Northwest. Phytopathology 80:784-788.

24. Otto, G., and Winkler, H. 1993. Colonization of rootlets of apple seedlings from replant soils by actinomycetes and endotrophic mycorrhiza. Acta Hortic. 324:53-59.

25. Savory, B. M. 1966. Studies on the occurrence and aetiology of specific replant diseases of perennial fruit crops. Ph.D. thesis. University of Lon- don, London.

26. Savory, B. M. 1966. Specific replant diseases causing root necrosis and growth depression in perennial fruit and plantation crops. Res. Rev. No. 1. Commonwealth Bureau of Horticulture, East Malling, England.

27. Simon, A., and Ridge, E. H. 1974. The use of ampicillin in a simplified selective medium for the isolation of fluorescent pseudomonads. J. Appl. Bacteriol. 37:459-460.

28. Slykhuis, J. T., and Li, T. S. C. 1985. Response of apple seedlings to biocides and phosphate fertilizers in orchard soils in British Columbia. Can. J. Plant Pathol. 7:294-301.

29. Smiley, R. W., and Uddin, W. 1993. Influence of soil temperature on Rhizoctonia root rot (R. solani AG 8 and $R$. oryzae) of winter wheat. Phytopathology 83:777-785.

30. Utkhede, R. S., Vrain, T. C., and Yorston, J. M. 1992. Effects of nematodes, fungi and bacteria on the growth of young apple trees grown in apple replant disease soil. Plant Soil 139:1-6.

31. Weller, D. M. 1986. Effects of wheat genotype on root colonization by a take-all suppressive strain of Pseudomonas fluorescens. (Abstr.) Phytopathology 76:1059.

32. Wescott, S. W., III, Beer, S. V., and Israel, H. W. 1987. Interactions between actinomycete-like organisms and young apple roots grown in soil conducive to apple replant disease. Phytopathology 77:1071-1077.

33. Willett, M., Smith, T. J., Peterson, A. B., Hinman, H., Stevens, R. G., Ley, T., Tvergyak, P., Williams, K. M., Maib, K. M., and Watson, J. W. 1994. Growing profitable apple orchards in replant sites: An interdisciplinary team approach in Washington state. HortTechnology 4:175-181. 